\title{
Vice, Crime, and Poverty: How the Western Imagination Invented the Underworld by Dominique Kalifa
}

Timothy J. Gilfoyle

Loyola University Chicago, tgilfoy@luc.edu

Follow this and additional works at: https://ecommons.luc.edu/history_facpubs

Part of the History Commons

\section{Author Manuscript}

This is a pre-publication author manuscript of the final, published article.

\section{Recommended Citation}

Gilfoyle, Timothy J.. Vice, Crime, and Poverty: How the Western Imagination Invented the Underworld by Dominique Kalifa. Labor, 17, 3: 137-139, 2020. Retrieved from Loyola eCommons, History: Faculty Publications and Other Works, http://dx.doi.org/10.1215/15476715-8349561

This Book Review is brought to you for free and open access by the Faculty Publications and Other Works by Department at Loyola eCommons. It has been accepted for inclusion in History: Faculty Publications and Other Works by an authorized administrator of Loyola eCommons. For more information, please contact ecommons@luc.edu.

\section{(c) (†) $\ominus$}

This work is licensed under a Creative Commons Attribution-Noncommercial-No Derivative Works 3.0 License. (c) Labor and Working-Class History Association, 2020. 
Vice, Crime, and Poverty: How the Western Imagination Invented the Underworld Dominique Kalifa

New York: Columbia University Press, 2019.

xiv + 278 pp., \$35 (cloth); \$34.99 (ebook).

Dominique Kalifa traces the emergence of the urban underworld in the Western world during the nineteenth and twentieth centuries. Vice, Crime, and Poverty represents a remarkable synthesis of a considerable primary and secondary literature on these subjects spanning numerous national histories, incorporating the work of Eric Hobsbawm, Michel Foucault, Bronislaw Geremek, Richard Evans, Alain Corbin, Louis Chevalier, Tyler Anbinder, and others. Kalifa is less interested in describing and analyzing the material conditions found in informal economies and subaltern subcultures and more concerned with the language and rhetoric embedded in discussions of crime and poverty. According to Kalifa, "the underworld arose from a representation, a cultural construction that was born at the intersection of literature, philanthropy, the desire for reform, and the moralizing of elites" (6).

Kalifa insightfully demonstrates how languages and vocabularies originating in the descriptions of the underworld by nineteenth-century contemporaries created inaccurate, misinformed, exaggerated, and sensationalized images of the poor and socially-marginal. Novelists, journalists, evangelical missionaries, social reformers, and participant observers seeking to inform and educate unwittingly created discourses centered on "sub-men" and "different races of people" (24), in essence les misérables. The foundations of the "lower depths" was rooted in Biblical cities such as Sodom and Babylon, ancient Rome, the rise of the "bad poor" in the thirteenth century, and "beggary" in the fifteenth (5). In the modern city, representations of vice, crime, and poverty "dramatized" the reality of inequality, serving as "a symptom, an antidote, and a spectacle" (62). According to Kalifa, "the invention of pauperism" 
intersected with a new "savagery" and "barbarism," ultimately creating a "rhetoric of terror" (60) conflating the working poor and laboring classes with "the dangerous classes" and "criminal classes" (63). This language was rooted in the physical city: "foul cellars," "underground rooms," the "bottom of the bottom" (16). The city was transformed into a symbolic sewer. No one escaped this "social imaginary," as the same "stigmatization" (68) infiltrated the fiction of Victor Hugo, the journalism of William Stead, the political treatises of Karl Marx and Frederick Engels, the photography of Jacob Riis, and the sociology of Robert Park.

Most convincing is Kalifa's demonstration of how the social imaginary associated with the criminal underworld embodied a form of "cultural globalization" $(35,75)$, indeed a "globalized . . . system of representations" (35). Eugène Sue's Les mystèries de Paris (1842-43) created an early "true crime" genre that was transnational and trans-Atlantic in scope. Provincial cities Rouen, Marseille, Nancy, Lille, and Belfort were soon the subject of similar melodramas. By the end of the century, Hamburg (1845), New York (1845), Berlin, Barcelona, Vienna, Boston, Naples (1847), Brussels (1850), Mexico City (1851), Stockholm (1852), Florence (1854), Lisbon (1854), Rio de Janeiro (1866), Chicago (1891), and Buenos Aires (1897) had their own Mysteries. Seeking to inform, educate, and mobilize the citizenry, these publications created a public discussion organized around sensationalism, hyperbole, and misinformation what we might call "fake news" today - that infused the multiple urban worlds of the nineteenth century. "The Mysteries no doubt constituted the first great phenomenon of cultural globalization," according to Kalifa (75).

Some social historians, however, will find Vice, Crime, and Poverty unsatisfying. Kalifa interprets virtually all written discussion of illicit behavior and informal economies as part of the "social imaginary." The Chicago School of Sociology (even the recent participant observation 
work of Sudhir Venkatesh) reflects a moral outlook similar to Sue's Mystèries. Empirical research cannot escape the oral vernacular or social imaginary associated with the underworld. Quoting George Orwell, Kalifa agrees that "Unfortunately, you do not solve the class problem by making friends with tramps" (115).

Inequality, however, is not a simple representation, social imaginary, or cultural construct. Industrialization and urbanization - unprecedented in scope, range, and time in the nineteenth century - generated new structures of inequality manifested in the "underworld," the "informal economy," the "vice district," the "subaltern society," call it what you want. These physical spaces, socio-economic institutions, and their local residents were not simply linguistic creations of Charles Dickens, Victor Hugo, or Edgar Allen Poe. They were grounded in real political economies and material cultures. Yet most accounts of the social reality of poverty, the built environment, and the social structures resulting from the new economy organized by the factory, Kalifa argues, fail to escape the linguistic straightjacket of the social imaginary. "The underworld is not a universe in itself," Kalifa writes. "It is always the inverse of the society above" (34). But by emphasizing "inversion" and exaggeration, Kalifa ignores the liminality of the multiple subcultures organized around illegal behaviors and poverty, how these subcultures frequently overlapped and intersected with the legal structures of the dominant culture, creating new forms of commercial sex, new kinds of illegal enterprise, new subcultures of social organization and even sexual expression.

For Kalifa, "real underworld situations remain elusive apart from the texts that convey them" (199). Any “documentary work," he argues, should "arouse suspicion" (199). Consequently, his is the "more nuanced position" (202). In one page (201), Kalifa dismisses a half-century of historiography on criminal subcultures (including E.P. Thompson, Eileen Yeo, 
Bronislaw Geremek, Louis Chevalier, among others). Ignoring the nuance found in that literature, Kalifa faults materially-grounded history writing for relying on "fragmentary data" and "a meager sample of witness testimony" (202). Any effort to comprehend this "nether world" remains incomplete, according to Kalifa. "The imaginary never stops influencing the reality" (204).

Kalifa emphasizes sensational fiction, while dismissing how historians interrogate sources, question "expert" testimony, acknowledge memoir bias, or concede the "constructed narratives" of courtroom testimony. But not all texts are equal. Historians of criminal subcultures and informal economies demonstrate that some documents - scripted and unscripted court testimony, published and unpublished criminal autobiographies - better convey the paradoxical, liminal complexity of informal economies and subaltern communities, however imperfectly. Indeed, does any text perfectly portray the past? Is the social imaginary of the underworld more intellectually impenetrable than the social imaginary of the ethnic ghetto, the segregated African American neighborhood, the "gold coast" community of any modern city? All may be socially constructed and known by "representations," but those images hardly deny the material reality of people's lives.

Timothy J. Gilfoyle, Loyola University Chicago 